\title{
Methane Gas Utilization from Organic Waste Volume in Tpa Puuwatu, Kendari City
}

\author{
Yuspian Gunawan ${ }^{1}$, Jenny Delly ${ }^{2}$, Ridway Balaka ${ }^{3}$, Salimin $^{4}$, Sudarsono ${ }^{5}$, \\ Budiman Sudia ${ }^{6}$, Abd Kadir ${ }^{7}$, Indrayati Galugu ${ }^{8}$, Bunyamin ${ }^{9)}$ \\ \{yuspiangunawanstmt@gmail.com¹ , enydelly09@gmail.com², bridway@yahoo.com³
}

Mechanic Engineering Department, Halu Oleo University, Kendari, Indonesia 1,2,3

\begin{abstract}
The purpose of this research was to determine the amount of waste in TPA Puuwatu and the volume of methane gas produced. It used a quantitative descriptive method with data obtained from related institutions, such as the Sanitation and Parks Office and the Central Statistics Agency. The survey location was TPA, which is a Final Waste Processing Site, Puuwatu in Kendari City.. The results showed that the average volume of waste from January to July 2018 was $5,278 \mathrm{~m} 3$, though the total was $32,667 \mathrm{~m} 3$ with potential waste $(\mathrm{Q})$ of $184.503,216 \mathrm{~kg} /$ day. The volume of methane gas produced was $15,360.3062 \mathrm{~m} 3 /$ day.
\end{abstract}

Keywords: Methane Gas, Organic Waste, Final Waste Processing Site (TPA)

\section{Introduction}

With increasing growth rate of population, municipal solid waste generation is expected to grow even faster, making the solid waste scenario much worse and a major bottleneck for development in Asian developing countries, like India.[1]

The energy-independent settlement in Kendari had a positive impact on some residents, especially around the city. The electricity in this area is generated from the utilization of organic waste. The byproducts are processed to produce methane $\left(\mathrm{CH}_{4}\right)$, which is used as fuel for power generation engines. [2]

In general, methane forms the main component of biogas and the simplest hydrocarbon. The main physical characteristics of methane include being colorless and odorless gas, highly flammable at levels between $5-15 \%$ and a molecular weight of 16.04 , specific gravity of 0.554 , boiling point of $1610 \mathrm{C}$, and water solubility of about $35 \mathrm{mg} / \mathrm{L}$ at a pressure of 1 atmosphere. [3]

Based on the data from the Central Statistics Agency (BPS) for 2017, Kendari City has a total of 370,728 population with a density of $54 / \mathrm{km} 2$ producing a lot of waste. To effectively address the waste issue, the local government has implemented the $3 \mathrm{R}$, which primarily means Reduce, Reuse, Recycle. Moreover, the government also carry out processing with Sanitary Landfill to produce methane.[4]

Around $60 \%$ of household waste is organic, while approximately $40 \%$ is inorganic. The amount of gas produced depends on the volume of organic waste. To determine the volume of waste in the TPA of Kendari City, a study analyzing methane gas utilization from the organic 
waste volume was conducted. The purpose of this research therefore was to determine the amount of waste per day and the volume of methane gas produced in the TPA Puuwatu. [5]

\section{Literature Review}

\subsection{Energy}

Energy sources can be classified as conventional, especially where they are obtained from sources available in limited quantities and cannot be regenerated. Generally, renewable energy is produced from natural sources such as the sun, wind, and water, which have the potential to be reproduced. These resources are always available and do not harm the environment. Conventional and renewable energy can be converted into secondary sources, such as electricity. It is often referred to as a carrier since it can be converted into other forms, such as mechanical work comfortably. In general, primary energy sources are needed to produce electricity.5]

In most of the recent EU member countries, as well as Spain and Greece, instead, sanitary landfilling is still the most-adopted waste management strategy (>50\%).[6]

\subsection{Organic Waste}

Waste is a material discarded from human and natural activities due to a lack of economic value. It can be defined as an unwanted residual material after the end of a process. It is a humanmade concept since, in natural processes, there is no waste, but only immovable products. Essentially, waste may either be in the form of a solid, liquid, or gas. In case it is released in the liquid or gaseous state, it referred to as emissions, a term linked with pollution. Generally, large amounts of waste come from industrial activities, such as mining, manufacturing, and consumption. Almost all industrial products become waste, with the amount released being approximately similar to what is consumed. [7]

1. Waste Based on the Source
a. Household
b. Agriculture
c. Office space
d. Company
e. Hospital
f. Market, etc.

2. Waste based on nature

a. Natural Waste

Waste produced is integrated through a natural recycling process, such as dry leaves in the forest that break down into the soil. Away from wildlife, these wastes might be problematic; for example, dry leaves in a residential environment.

b. Human Waste

Human waste is a term commonly used to refer to the byproducts of human digestion, such as feces and urine. These wastes can be hazardous since they lead to diseases caused by viruses and bacteria. One of the main developments in human dialectics is the reduction of disease transmission through human waste with hygiene and sanitary, including the development of plumbing theory. Also, human waste can be reduced and reused, for example, through a waterless urinal system. 


\section{c. Consumption Waste}

This is waste produced from the use of goods that are often thrown in the trash by humans. It is still far smaller than the waste generated from mining and industrial processes.

The municipal solid waste (MSW) generated by households is considered the third largest anthropogenic source of methane (CH4) emissions, constituting $11 \%$ of all global CH4 emissions.[8]

The municipal solid waste (MSW) generated by households is considered the third largest anthropogenic source of methane (CH4) emissions, constituting $11 \%$ of all global $\mathrm{CH} 4$ emissions. [9]

More than half of that trash ends up in land ills where it generates methane, a greenhaouse gas thats over 20 times more potent than carbon dioxida. This methane from waste can be used to produce energy. [10]

\subsection{Methane Gas}

Methane has been rising rapidly in the atmosphere over the past decade, contributing to global climate change. Methane is the second most important greenhouse gas behind carbon dioxide causing global climate change, contributing approximately $1 \mathrm{Wm}^{-2}$ to warming when indirect effects are included compared to $1.66 \mathrm{Wm}^{-2}$ for carbon dioxide.[11]

Atmospheric methane levels rose steadily during the last few decades of the 20th century before leveling off for the first decade of the 21st century. Since 2008, however, methane concentrations have again been rising rapidly (Fig. 1a). This increase, if it continues in coming decades, will significantly increase global. [12]

The problem of solid waste management has been increased due to rapid increase of population, intensive agriculture and industrialization. Accumulation and improper methods of disposal of waste, including heaping, dumping, land filling and incineration, cause pollution and hazards to human and environmental health.[13]

\section{Calculations}

\section{4}

\subsection{Amount of Total Solid (TS), Volatile Solid (VS). and Biogas Productionc}

The calculation is based by Tanya Mc. Donald, Gopal Achari, and Bimbola Abiola in the article "Feasibility of Increased biogas production from the co-digestion of agricultural, municipal, and agro-industrial wastes in rural communities." By testing biogas production from organic waste, the value of waste to Total Solid (TS) and Volatile Solid (VS) is obtained, as shown in table 1. In this literature, the value of VS is equivalent to the biogas produced.

Table 1. Potential for Total Solid (TS), Volatile Solid (VS) and Biogas Production of organic waste.[14]

\begin{tabular}{cccc}
\hline Material Type (kg) & Total Solid (TS) (\%) & $\begin{array}{c}\text { Volatile Solid (VS) } \\
(\%)\end{array}$ & $\begin{array}{c}\text { Biogas Production } \\
\left(\mathrm{m}^{2} / \mathrm{kg} \text { TS }\right)\end{array}$ \\
\hline Organic Waste & 27.7 & 74.1 & 0.676 \\
& & & \\
\hline
\end{tabular}


From the table, the equation for calculating Total Solid, Volatile Solid, and biogas production is (Agung Sulistyo, 2010);

$\mathrm{TS}=27.7 \% \times \mathrm{Q}$

$\mathrm{VS}=74.1 \% \times \mathrm{TS}$

$\mathrm{VBS}=0.676 \times \mathrm{VS}$

Description:

$\mathrm{Q}=$ Potential Waste $(\mathrm{kg} /$ day $)$

TS $=$ Total Solid

VS $\quad=\quad$ Volatile Solid (kg/day)

VBS $=$ Biogas production volume $\left(\mathrm{m}^{3} /\right.$ day $)$

\subsection{Amount of Methane produced}

Calculation of the potential amount of methane produced in a landfill process.

Table 2. The total volume of methane gas from organic waste [14]

\begin{tabular}{|l|l|}
\hline Produksi Biogas $\left(\left(\mathrm{m}^{3} / \mathrm{hari}\right)\right.$ & Jumlah gas metan $(\%)$ \\
\hline VBS & 60
\end{tabular}

\begin{tabular}{|l|l|}
\hline VBS & 60
\end{tabular}

From the table above, the equation for calculating the gas is

$\mathrm{VGM}=60 \% \times \mathrm{VBS}$

Description:

$\mathrm{VGM}=$ Volume of methane gas (m3/day)

$\mathrm{VBS}=$ Volume of Biogas production (m3/day)

\section{Data Analysis}

\subsection{Data of Waste Volume from January to July 2018}

The data was obtained from the Technical Implementation Unit (UPTD) of TPA Puuwatu, as follows shown in table 3 below.

Table 3. Total volume of waste per month in 2018

\begin{tabular}{|l|l|}
\hline Month & Volume $\mathrm{m}^{3}$ \\
\hline January & $4,950.5$ \\
February & $4,410.0$ \\
March & $4,560.0$ \\
May & $6,330.5$ \\
June & $5,892.5$ \\
July & $6,523.5$ \\
\hline Total & 32,667 \\
\hline
\end{tabular}

\subsection{Biogas Energy Capacity from Waste Raw Materials} month.

The calculation of biogas energy capacity from raw materials in TPA Puuwatu per

1. January 2018

For conversion from $\mathrm{m} 3$ to $\mathrm{kg}$, the values are multiplied by 169.44 . Therefore,

$4950.5 \mathrm{~m}^{3}$ is equivalent to $=4950.5 \times 169.44$

$=838,812.7 \mathrm{Kg} / \mathrm{month}$ 


$$
\begin{aligned}
& =838,812.7 / 30 \text { day } \\
& =27,960.424 \mathrm{Kg} / \mathrm{day} \\
& \mathrm{TS}=27.7 \% \mathrm{x} \mathrm{Q} \\
& =27.7 \% \times 27,960.424 \\
& =7,745.037448 \mathrm{~kg} \\
& \mathrm{VS}=74.1 \% \mathrm{x} \mathrm{TS} \\
& =74.1 \% \times 7,745.037448 \mathrm{~kg} \\
& =5,739.0727 \mathrm{~kg} \\
& \mathrm{VBS}=0.676 \times \mathrm{VS} \\
& =0.676 \times 5,739.0727 \mathrm{~kg} \\
& =3,879.613 \mathrm{~m}^{3}
\end{aligned}
$$

Complete data from January to July is shown in the table below.

Table 4. Q and VBS Values in 2018

\begin{tabular}{|l|l|l|}
\hline Month & Q $(\mathrm{kg} /$ day $)$ & VBS $\left(\mathrm{m}^{3}\right)$ \\
\hline January & $27,960.424$ & $3,879.613$ \\
February & $24,907.68$ & $3,456.0336$ \\
March & $25,754.88$ & $3,573.5857$ \\
May & $35,754.664$ & $4,961.0931$ \\
June & $33,280.84$ & $4,617.8414$ \\
July & $36,844.728$ & $5,112.3435$ \\
\hline TOTAL & $184,503.216$ & $25,600.5103$ \\
\hline
\end{tabular}

\subsection{Methane gas production}

Energy production in biogas is proportional to the yield of methane gas.

$\mathrm{VGM}=60 \% \times \mathrm{VBS}$

Description:

$\mathrm{VGM}=$ Methane gas production $\left(\mathrm{m}^{3} /\right.$ day)

VBS = Biogas production volume $\left(\mathrm{m}^{3} /\right.$ day $)$

1. January 2018

$$
\begin{array}{ll}
\text { VBS } & =3,879.613 \mathrm{~m}^{3} \\
\text { VGM } & =60 \% \times \mathrm{VBS} \\
& =60 \% \times 3,879.613 \\
& =2,327.7678 \mathrm{~m}^{3} / \text { day }
\end{array}
$$

Complete data from January to July is shown in table the below.

Table 5. Value of Methane Gas Production (VGM) in 2018

\begin{tabular}{|l|l|l|}
\hline Month & VBS $\left(\mathrm{m}^{3}\right)$ & VGM $\left(\mathrm{m}^{3} /\right.$ hari $)$ \\
\hline January & $3,879.613$ & $2,327.7678$ \\
February & $3,456.036$ & $2,073.6202$ \\
March & $3,573.5857$ & $2,144.1514$ \\
May & $4,961.0931$ & $2,976.6559$ \\
June & $4,617.8414$ & $2,770.7048$ \\
July & $5,112.3435$ & $3,067.4061$ \\
\hline TOTAL & $25,600.5103$ & $15,360.3062$ \\
\hline
\end{tabular}

\section{Conclusions}

Based on the findings, this study concludes that; 
The amount of organic waste production in TPA Puuwatu in 2018 was $32,667 \mathrm{~m}^{3}$ or $5,535,096.48 \mathrm{Kg} /$ Month. However, the amount of organic waste in 2018 was meager compared to the production in big cities such as in Surabaya, Palembang, Bekasi, Denpasar, Jakarta, Makassar, Manado, and South Tangerang with an average of 1500 to 2800 tons/day. Other essential values include; potential waste (Q) 184,503.216 kg/day, volume of Biogas (VBS) and methane production $25,600.5103 \mathrm{~m} 3$ and $15,360.3062 \mathrm{~m} 3 /$ day, respectively

\section{References}

[1] Khajuria, Anupam, et al. "Municipal solid waste management: Reduction of methane emission from landfill disposal system in India." International Journal of Applied Environmental Sciences 4.2 (2009): 203-209.

[2] Tasnim, Tasnim, and Maria Inge Lusida. "EFFECTIVITY OF COMMUNITY INVOLVEMENT IN FOOD CONTROL TO INCREASE THE QUALITY OF FAST FOOD IN KENDARI CITY INDONESIA."

[3] Al Asri, LM Arison, Tachrir Tachrir, and Abdul Djohar. "PERANCANGAN JARINGAN DISTRIBUSI DARI PEMBANGKIT LISTRIK TENAGA SAMPAH (PLTSa) PUUWATU, KOTA KENDARI." Jurnal Fokus Elektroda: Energi Listrik, Telekomunikasi, Komputer, Elektronika dan Kendali) 3.2 (2018).

[4] Sinolungan, Meldi TM, et al. "The geochemical characteristics of sediment in Tondano Lake, Indonesia: heavy metals and organic matter contents, and grain size distribution." Paddy and Water Environment 6.3 (2008): 341-348.

[5] Sovacool, Benjamin K., and Ira Martina Drupady. Energy access, poverty, and development: the governance of small-scale renewable energy in developing Asia. Routledge, 2016.

[6] Lombardi, Francesco, Giulia Costa, and Piero Sirini. "Analysis of the role of the sanitary landfill in waste management strategies based upon a review of lab leaching tests and new tools to evaluate leachate production." Revista Ambiente \& Agua 12.4 (2017): 543-555.

[7] Damanhuri, Enri, and Tri Padmi. "Pengelolaan sampah." Diktat kuliah TL 3104 (2010): 5-10.

[8] Singh, Chander Kumar, Anand Kumar, and Soumendu Shekhar Roy. "Quantitative analysis of the methane gas emissions from municipal solid waste in India." Scientific reports 8.1 (2018): 2913.

[9] Singh, Chander Kumar, Anand Kumar, and Soumendu Shekhar Roy. "Quantitative analysis of the methane gas emissions from municipal solid waste in India." Scientific reports 8.1 (2018): 2913.

[10] Dworkin, Stephen. "E-The Environmental Magazine." (2011).

[11] Change, IPCC Climate. "The physical science basis. Contribution of working group I to the fourth assessment report of the intergovernmental panel on climate change." Manning, M., Chen, $Z$., Marquis, M., Averyt, KB, Tignor, M., and Miller, HL, Cambridge University Press, Cambridge, UK and New York, NY, USA 996 (2007): 2007.

[12] Nisbet, E. G., et al. "Very strong atmospheric methane growth in the 4 years 2014-2017: Implications for the Paris Agreement." Global Biogeochemical Cycles 33.3 (2019): 318-342. 
[13] Dandotiya, Puneeta, et al. "An eco-friendly management of household organic waste." Octa Journal of Environmental Research 3.2 (2015).

[14] Prayugi, Ginanjar Eko, Sumardi Hadi Sumarlan, and Rini Yulianingsih. "Pemurnian Biogas dengan Sistem Pengembunan dan Penyaringan Menggunakan Beberapa Bahan Media." Jurnal Keteknikan Pertanian Tropis dan Biosistem 3.1 (2014): 7-14. 